\title{
PREECLAMPSIA - PREDICTION AND MONITORING FACTORS
}

Jovan Rudic ${ }^{1}$, Sasa Raicevic ${ }^{2,3}$ and Goran Babic ${ }^{4,5}$

${ }^{1}$ The Obstetrics and Gynaecology Clinic Narodni Front, Belgrade, Serbia;

${ }^{2}$ Clinic of Gynecology and Obstetrics, Clinical Centre of Montenegro, Podgorica, Montenegro;

${ }^{3}$ University of Montenegro, Medical faculty, Department of Gynecology and obstetrics, Podgorica, Montenegro

${ }^{4}$ University of Kragujevac, Faculty of Medical Sciences, Department of Gynecology and obstetrics, Kragjevac, Serbia

${ }^{5}$ The O bstetrics and Gynaecology Clinic, Clinical center "Kragujevac", Kragujevac, Serbia

\author{
PREEKLAMPSIJA - FAKTORI PREDVIĐANJA I PRAĆENJA \\ Jovan Rudić ${ }^{1}$, Saša Raičević́ ${ }^{2,3}$ i Goran Babić ${ }^{4,5}$ \\ ${ }^{1}$ Klinika za ginekologiju i akušerstvo Narodni Front, Beograd, Srbija \\ ${ }^{2}$ Klinika za ginekologiju i akušerstvo, Klinički centar Crna Gora, Podgorica, Crna Gora \\ ${ }^{3}$ Univerzitet u Podgorici, Medicinski fakultet, Katedra za ginekologiju i akušerstvo, Podgorica, Crna Gora \\ ${ }^{4}$ Univerzitet u Kragujevcu, Fakultet medicinskih nauka, Katerda za ginekologiju i akušerstvo, Kragujevac, Srbija \\ ${ }^{5}$ Klinika za ginekologiju i akušerstvo, Klinički centar Kragujevac, Kragujevac, Srbija
}

\begin{abstract}
Preeclampsia is one of the leading causes of maternal and perinatal morbidity and mortality, usually characterized by hypertension and proteinuria. Despite high incidence of preeclampsia the pathophysiological basis of preeclampsia is still not clear and there are a number of mechanisms and signaling pathways that intertwine. It is very important to develop specific and reliable predictive algorithms in order to enable early initiation of therapy due to facts that incidence of preeclampsia has upward trend and that cause adverse maternal and fetal outcome. Some of the most commonly used methods for prediction of preeclampsia include uterine artery Doppler velocimetry, determination of some microRNA, such as miR-210, and assessment of various pro-angiogenic and anti-angiogenic factors from blood. Angiogenic factors that possibly have most important role in pathogenesis of preeclampsia are vascular endothelial growth factor (VEGF) and placental growth factor (PlGF), which promote angiogenesis, and soluble fms-like tyrosine kinase-1 (sFlt1) and soluble form of endoglin (s-Eng), which exhibit anti-angiogenic properties. Aggravating circumstance is that preeclampsia has heterogeneous origin, and due to this fact, the value of individual markers can vary signifcantly. There is a constant tendency for creating comprehensive algorithm for prediction of preeclampsia which would be sufficiently specific and sensitive, and in the same time cheap and available. In that sense, new clinical studies are needed to show the most effective combination of parameters in the predeclampsia prediction.
\end{abstract}

Keywords: preeclampsia; prediction; Doppler velocimetry; microRNA; angiogenic factors.

\section{SAŽETAK}

Preeklampsija je jedan od vodećih uzroka materinskog $i$ perinatalnog morbiditeta i mortaliteta, koju najčešće karakterišu hipertenzija i proteinurija. Uprkos visokoj incidenciji patofiziloška osnova preeklampsije nije dovoljno jasna i postoji veliki broj mehanizama $i$ signalnih puteva koji se medusobno prepliću. Vrlo je važno razviti specifične i pouzdane algoritme za predviđanje preeklampsije kako bi se omogućilo rano započinjanje terapije u skladu sa činjenicom da incidencija preeklampsije ima uzlazni trend i uzrokuje neželjeni maternalni i fetalni ishod porođaja. Neki od najčešćih metoda koje se koriste za predvidanje nastajanja preeklampsije podrazumevaju Dopler uterine arterije, odredivanje pojedinih mikroRNK, poput miR-210, kao i odredivanje razlicitih proangigenih $i$ antiangiogenih faktora iz periferne krvi. Angiogeni faktori koji možda imaju najznačajniju ulogu u patogenezi preeklampsije su vaskularni endotelni factor rasta (VEGF) i placentalni factor rasta (PlGF), koji pospešuju angiogenezu, $i$ solubilna fms-slična tirozin kinaza-1 (sFlt1) $i$ solubilni oblik endoglina (s-Eng), koji ispoljavaju antiangiogena svojstva. Otežavajuća okolnost je činjenica da preeklampsija ima heterogeno poreklo, i u skladu sa tim vrednosti pojedinih markera mogu znatno da variraju. Postoji konstantna težnja za stvaranje sveobuhvatnog algoritma za predvidanje nastajanja preeklampsije koji bi bio dovoljno specifičan $i$ senzitivan, a u isto vreme jeftin $i$ dostupan. $U$ tom smislu, potrebne su nove kliničke studije kako bi se obrazovala najefikasnija kombinacija parametara za predvidanje nastajanja preeklampsije.

Ključne reči: preeklampsija; predikcija; Doppler; mikroRNK; angiogeni faktori.

\section{sciendo \\ UDK: 618.3-008.6}

Ser J Exp Clin Res 2019; 20 (4): 287-294

DOI: $10.2478 /$ sjecr-2018-0026
Corresponding author: Goran Babic, MD, PhD University of Kragujevac, Faculty of Medical Sciences, Department of Gynecology and obstetrics, SERBIA Phone: +381 34306800 ; Fax: + 381 34 306800/ext 112; E-mail: ginbabic@eunet.rs 


\section{ABBREVIATIONS}

AP-1 - activated protein 1

BMP - bone morphogenetic protein CRH - corticotrophin releasing hormone

CYR61- cysteine-rich protein 61

DNA - deoxyribonucleic acid

eNOS - endothelial nitric oxide synthase HDP - hypertensive disorders of pregnancy

LPS - lipopolysaccharides

microRNA - microribonucleic acid MPV - mean platelet volume

$\mathbf{N F}-\mathbf{k B}$ - nuclear factor- $\mathrm{kB}$

NO - nitric oxide

PAPP-A - pregnancy associated plasma protein A
PC - platelet count

PDW - platelet distribution width

PI - pulsatility index

Plcr - platelet large cell ratio

PIGF - placental growth factor

PP13 - placental protein 13

qRT-PCR - quantitative reverse transcription-polymerase chain reaction

RI - resistance index

RNA - ribonucleic acid

sEng - soluble endoglin

sFlt-1 - soluble fms-like tyrosine kinase-1

TGF- $\beta$ - transforming growth factor $\beta$

VEGF - vascular endothelial growth factor

\section{INTRODUCTION}

Preeclampsia represents one of the hypertensive disorders of pregnancy (HDP) and one of the leading causes of maternal and perinatal morbidity and mortality worldwide complicating $2 \%-8 \%$ of pregnancies $(1,2)$. According to the American College of Obstetricians and Gynecologists there are four major hypertensive disorders encompassed within HDP: 1) chronic hypertension, 2) preeclampsia and eclampsia, 3) hronic hypertension with superimposed preeclampsia, and 4) gestational hypertension (3). The International Society for the Study of Hypertension in Pregnancy as an additional category also lists the "white coat hypertension" In addition to the fact that HDP make up a large share of maternal and perinatal mortality, another worry is related to the results of the studies that indicate that incidence of the HDP continues to increase (4). Clinical diagnosis of preeclampsia is based on several criteria: 1 ) blood pressure above $140 / 90 \mathrm{mmHg}$ in two separate measurements separated by an interval longer than 4 hours, or blood pressure above $160 / 110 \mathrm{mmHg}$ in two measurements separated shorter interval, after 20 week of gestation in previously normotensive woman; 2) proteinuria which exceeds $300 \mathrm{mg} / 24 \mathrm{~h}$; 3) in the absence of proteinuria, additional criteria include: thrombocytopenia, renal failure, disturbance of liver function, pulmonary edema, as well as any symptom related to the disorder of the function of the nervous system $(3,5)$. If preeclampsia progresses and seizures occur, preeclampsia passes into eclampsia. In the fetus preeclampsia causes premature birth and growth restriction, while in women with preeclampsia increases risk for other diseases, such as renal failure, stroke and cardiovascular disease (6).

There are many conditions recognized as risk factors for development of preeclampsia (Table 1). Nulliparous women have a three times greater risk for development of preeclampsia in comparison to multiparous women. Also in women with pregnancies complicated with preeclampsia there is increased risk for recurrence in subsequent pregnancies. Age is also a risk factor, so that pregnant women over 40 years also have an increased risk of developing preeclampsia (7). Risk factors for preeclampsia also include family history for preeclampsia, twin pregnancy, antiphospholipids antibodies and thrombophilia, preexisting diabetes, preexisting chronic hypertension or increased blood pressure, preexisting renal and autoimmune disease, as well as increased body mass index $(8,9)$.

Despite high and increasing incidence of preeclampsia the pathophysiological basis of preeclampsia is still not clear and there are a number of mechanisms and signaling pathways that intertwine. Preeclampsia is usually defined as a syndrome of maternal systemic inflammatory response that affects various organ systems, and according to the current hypothesis preeclampsia is caused by placental dysfunction which takes place in two stages $(10,11)$. The first stage implies poor placentation which occurs during first half of pregnancy, between 8 and 18 week of gestation. During this stage clinical symptoms are absent, but Doppler's ultrasound analysis of blood flow velocity in uterine arteries indicate changes that could affect blood flow in spiral arteries $(12,13)$. Ischemic and reperfusion injury of placenta due to disturbed perfusion of placenta causes increased production of reactive species and oxidative stress,

Table 1. Risk factors for preeclampsia onset.

\section{Nulliparity}

\section{Advanced maternal age}

Previous pregnancies complicated with preeclampsia

Pregnant women of advanced age

Family history of preeclampsia

Twin pregnancy

Preexisting chronic hypertension

Preexisting renal and autoimmune disease

Increased body mass index and obesity 
as well as synthesis and release of proinflammatory mediators from syncytiotrophoblast. These mediators induce clinical manifestations of preeclampsia in second half of pregnancy, which represents the second phase. Proinflammatory mediators involved in occurrence of preeclampsia include: soluble fms-like tyrosine kinase-1 (sFlt-1), soluble endoglin (sEng), leptin, activin-A, corticotrophin releasing hormone $(\mathrm{CRH})$, serum placental protein 13 (PP13), and pregnancy associated plasma protein A (PAPP-A) (14-17). There were various attempts to provide the best prediction algorithm for preeclampsia, as well as to set aside parameters which would enable the most adequate monitoring of preeclampsia which has already been diagnosed.

\section{UTERINE ARTERY DOPPLER IN PREECLAMPSIA PREDICTION}

Attempts to use ultrasound and Doppler's effects in the prediction of preeclampsia have a relatively long history. Namely, one of the first tries to use Doppler velocimetry in analysis of blood flow and pressures in women with HDP was conducted by Fleischer and colleagues during the eighties of the last century (18). These authors compared ratio between systolic and diastolic pressure in normal pregnancies and HDP, and concluded that systolic/diastolic ration physiologically does not exceed 2.6. On the other hand when this ratio is higher pregnancy can be complicated by premature birth, intrauterine growth retardation and maternal preeclampsia. During early pregnancy, as well as in nonpregnant state, Doppler analysis show low end-diastolic velocity and early diastolic notch. Namely, normal shape of uterine waveform consist steep systolic slope, early diastolic notch and a small flow of blood during the diastole. As the pregnancy progresses the resistance to blood flow decreases, diastolic notch is gradually removed and diastolic blood flow increases (19). Increase of blood flow reaches peak between $20^{\text {th }}$ and $24^{\text {th }}$ week of pregnan$\mathrm{cy}$, and at the end of pregnancy uterine arteries blood flow amounts $970 \mathrm{ml} / \mathrm{min}$ (20). In HDP resistance to blood flow in uteroplacental circulation is high, which is transmitted upstream to the uterine arteries and can be detected through increased pulsatility index (PI) or resistance index (RI) (13).

In cohort study performed by Sharma and colleagues it was shown that single uterine artery Doppler scan in second trimester of pregnancy (between 20 and 23 week of gestation), combined with other risk factors such as maternal age over 34 years and chronic hypertension, would clarify what pregnancies need further supervision (21). Pedroso and coworkers analyzed 30 large cohort studies and randomized trials which dealt with prediction possibility of uterine artery Doppler in occurrence of preeclampsia and fetal growth retardation (22). They concluded that of analysis of uterine artery PI by Doppler has low sensitivity and prediction capability, but in combination with other biochemical markers or analysis of maternal risk factors its sensitivity increases, making it an acceptable and useful part of the preeclampsia prediction algorithms. Tan and coauthors analyzed results from three previously reported prospective non-intervention screening studies, in a combined total of 61,174 singleton pregnancies (23). From this total number of analyzed pregnancies, 2.9\% developed preeclampsia. These authors confirmed conclusion of previously mentioned study, and showed that analysis of maternal factors, uterine artery PI by Doppler, mean arterial pressure and serum placental growth factor (PLGF) enabled prediction over $90 \%$ of preeclampsia. Abdel Razik and colleagues investigated the interconnection between Doppler ultrasound parameters: diastolic notch, PI and RI, and platelet indices: platelet count (PC), mean platelet volume (MPV), platelet distribution width (PDW) and platelet large cell ratio (Plcr) (24). They analyzed 270 normal pregnant women between $20^{\text {th }}$ and $24^{\text {th }}$ week of gestation and showed that patients with preeclampsia had higher frequency of diastolic notching, as well as higher PI and RI, combined with significant increase of MPV and PDW. Also, patients with disturbed Doppler parameters and platelet indices had higher risk to develop a severe form of preeclampsia. Another investigation dealt with possibility of prediction of early and late preeclampsia through analysis of placental volume and placental blood flow, and results showed that pregnant women with preeclampsia have had lower placental volume and higher uterine PI compared to healthy pregnancies (25). Results of longitudinal study conducted by Porto and coworkers indicated that all pregnancies complicated with early onset of preeclampsia have had significantly higher uterine artery PI between $16+0$ and $19+6$ weeks of gestation (26). Navaratnam and colleagues went a step further, and compared PlGF tests and the sFlt-1/PlGF ratio with abnormal uterine artery Doppler (27). Results of their investigation showed significant association between PlGF or sFlt-1/PlGF ratio with results of Doppler parameters.

Taken all together, uterine artery Doppler can be used for prediction and monitoring of preeclampsia, but in order to increase sensitivity and specificity uterine artery Doppler should be combined with estimation of other markers.

\section{ROLE OF MICRO-RNA IN PREECLAMPSIA}

Ribonucleic acid (RNA) is polymeric molecule that have crucial role in deciphering of information within the deoxyribonucleic acid (DNA). Three various forms of RNA molecules take part in this process: messenger RNA (mRNA), which arises from the transcription process from DNA and contains information regarding the structure composition of proteins, transfer RNA (tRNA), which enables transfer of appropriate amino acid to ribosome, and ribosomal RNA (rRNA), which participates in the protein synthesis itself as part of the ribosome. In 1993 another form of RNA was discovered, micro RNA (microRNA) for 
which it turns out to have a number of key roles in the body (28). The fact that microRNAs are ubiquitously present in viruses, plants and animals depict their evolutionary necessity and importance. These small molecules, containing 20 to 24 nucleotide bases, have pivotal roles in processes such as regulation of cell cycle and regeneration, immunity, normal function of various tissues and organs, but on the other hand their role is recognized also in different pathological states, including carcinomas (29-33). Until now, there are more than 28,000 microRNAs which have been indentified in various species, and of that number 2654 are human microRNAs (34).

Pineles and colleagues firstly described the discrepancy in expression of microRNAs in placental tissue from patients with preeclampsia and control group of women with preterm labor and delivery (35). Namely, authors analyzed expression of 157 different microRNAs, using real-time quantitative reverse transcription-polymerase chain reaction (qRT-PCR), and found that two microRNAs, miR-182 and miR-210, had significantly higher expression in samples of placenta tissues of women with preeclampsia. Further, Zhang and colleagues firstly described negative correlation between expression of miR-155 and cysteine-rich protein 61 (CYR61) (36). CYR61 is important angiogenic regulator and has important role in placental angiogenesis (37). It was previously showed that expression of CYR61 in preeclamtic placental tissue has been reduced, thus reveling new mechanism in development of preeclampsia. It is also shown that stimulation of human-trophoblast-derived cells with lipopolysaccharides (LPS) leads to increment of miR-155, transcription factor activated protein 1 (AP-1) and nuclear factor (NF)- $\mathrm{kB}$, suggesting the role of miR-155 in process of syncytialization, as well as in pathogenesis of preeclamsia (38). Enquobahrie and colleagues found differences in expression of eight microRNAs in placental tissues of women with preeclampsia and women with normal pregnancy and labor using qRT-PCR (39). Results of this investigation showed up regulation of miR-210, and down regulation of seven other microRNAs (miR-328, miR-584, miR-139-5p, miR-500, miR-1247, miR-34c-5p and miR1). Overexpression of miR-210 under hypoxic conditions, which exist in preeclampsia, is related to NF- $\mathrm{KB}$ transcriptional factor p50, suggesting another mechanism involved in pathogenesis of preeclampsia. Furthermore, miR-210 modulates mitochondrial respiration and reduces oxygen consumption (40). Gunel and coworkers found increased plasma levels of miR-210 in pregnant women with preeclampsia, as well as decreased levels of miR-152 (41). Placenta-associated serum exosomal miR-155 derived from patients with preeclampsia caused decreased expression of endothelial nitric oxide synthase (eNOS) in primary human umbilical vein endothelial cells, and thus decreased production of nitric oxide (NO) (42).

In order to assess the possibility of prediction of preeclampsia by analyzing microRNAs from peripheral blood buffy coat samples of pregnant women, Winger and coauthors investigated 30 microRNAs (43). Authors performed
qRT-PCR analysis on samples of 48 pregnant women collected during first trimester of pregnancy $(11 \pm 13$ weeks gestation), of whom 8 had preeclampsia. Of 30 investigated microRNAs, eight is included in panel (miR-1267, miR-148a, miR-196a, miR-33a, miR-575, miR-582, miR210 and miR-16), and data showed that investigation of maternal immune cells may provide early prediction of preeclampsia and enable adequate response. On the other hand, Luque and coworkers based on the results of previously conducted investigation made quite opposite conclusion (44). Of 754 analyzed microRNAs from pregnant women with preeclampsia and healthy pregnancies, 63 of them were continuously registered in samples, but only 15 were differently represented. Further statistical analysis indicated that there were not significant differences in presence any of them in sera of pregnancies with preeclampsia and healthy pregnancies, so author concluded identification of microRNAs from maternal serum samples during first trimester is not a reliable predictor for development of preeclampsia.

Bearing in mind all above results it can be concluded that microRNAs have important role in pathogenesis of preeclampsia. On the other hand, predictive value of microRNAs determination depends on type of sample and time of sampling (week of gestation). In order to provide good predictive model which include analysis of microRNAs future investigation are necessary. These investigations will also provide new insights into roles of microRNAs in pathophysiology of preeclampsia and other HDP.

\section{ANGIOGENIC FACTORS IN PREECLAMPSIA}

Various circulating factors that affect angiogenesis take part in pathogenesis of preeclampsia. These factors can be classified as pro-angiogenic and anti-angiogenic and their imbalance actually is crucial in onset of preeclampsia. Decreased expression of vascular endothelial growth factor (VEGF) and placental growth factor (PIGF), which promote angiogenesis, combined with increased expression of soluble fms-like tyrosine kinase-1 (sFlt1) and soluble form of endoglin (s-Eng), which exhibit anti-angiogenic properties, are most often referred to as the focus of the preeclampsia pathogenesis.

The vascular endothelial growth factor (VEGF) is proangiogenic factor mostly synthesized by endothelial cells, macrophages, T-cells, tumor cells and cytothrophoblast in response to stimulation by hypoxia or various mediators (interleukins, transforming growth factor $\beta$ - TGF- $\beta$, platelet derived growth factors) (45). There are five members of VEGF family in mammals, VEGF-A, VEGF-B, VEGF-C, VEGF-D and placental growth factor (PlGF). When only the VEGF is mentioned, it is thought of VEGF-A, because it is predominant form. All VEGFs are generated as alternative splice variants of mRNA from the same gene located on chromosome 6 which contains 8 exons $(46,47)$. VEGFs can achieve their effect by acting on two receptor fami- 
PHYSIOLOGICAL PREGNANCY

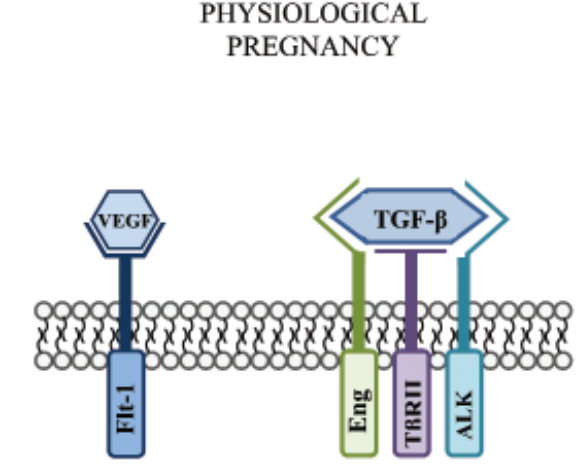

PREGNANCY COMPLICATED BY PREECLAMPSIA

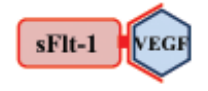

Figure 1. Role of angiogenic factors in pathogenesis of preeclampsia.

sEng - soluble endoglin; sFlt-1 - soluble fms-like tyrosine kinase-1; TGF- $\beta$ - transforming growth factor $\beta$; VEGF - vascular endothelial growth factor.

lies, VEGF receptors (VEGFR) and neuropilin receptors. VEGFR belong to tyrosine kinase receptors, and there are three types of them: VEGFR-1 (or fms-like tyrosine kinase - Flt-1), VEGFR-2 (or murine Flk-1) and VEGFR-3 (or Flt4), and there are two neutrophilin molecules: neutrophilin 1 and neutrophilin 2 (46). VEGF is very important in maintenance of fenestrated and sinusoidal epithelium, so the symptoms in preeclampsia are the most pronounced in organs in which these types of epithelia are present (kidney, liver). Angiogenesis is process of crucial importance in embryogenesis and growth, and due to that fact the physiological regulation of angiogenesis during pregnancy by above mentioned growth factors is also undoubtedly crucial. The main source of PlGF is placenta, and its level is low in the first trimester of normal pregnancy, with its concentration increasing from 11 week of gestation, reaching peak at 30 week of gestation, followed by decrease (48). PIGF enhances action of VEGF by competitive binding to VEGFR-1 and thus enabling the VEGF to bind the VEGFR-2 which has higher activity. PlGF also magnify the effects of VEGF binding to VEGFR-2, via mechanisms such as intermolecular transphosphorylation of VEGFR-2.

Soluble form of Flt-1 - sFlt-1, binds VEGF and PlGF, thereby reducing their availability in circulation (Figure 1). Due to the mentioned fact arise antagonistic properties of Flt-1 in relation to VEGF and PIGF. In preeclampsia sFlt-1 is mainly produced by syncytiotrophoblast, while its expression is regulated by hypoxia-inducible transcription factor (HIF) (49). Certain amount of sFlt-1 is present in circulation of healthy and non-pregnant women, indicating the physiological role of sFlt-1 in regulation of VEGF level (50). Hypothesis regarding action of sFlt-1 implies the existence of endothelial threshold for sFlt-1 concentration. When concentration of sFlt-1 exceeds that threshold, concentration of VEGF and PIGF decreases leading to endothelial dysfunction and preeclampsia (51). In women with previously disturbed endothelial function, regarding states such as hypertension, diabetes or obesity, mentioned threshold is lower, so they are consequently more vulnerable to preeclampsia. Endoglin is an integral transmembrane glycoprotein, which is also referred as endothelial marker CD105 (52). Endoglin is part of TGF- $\beta$ complex, and act as co-receptor for TGF- $\beta 1$ and TGF- $\beta 3$ but not TGF- $\beta 2$ (53). Membrane endoglin, through its short cytoplasmic domain, is connected with endothelial nitric oxide synthase (eNOS) and thus has important role in regulation of eNOS activity and NO bioavailability (54). The form of endoglin that could be found in circulation in some conditions including preeclampsia is referred to as soluble endoglin (sEng) (55). TGF- $\beta$ has important role in regulation of endothelial and vascular homeostasis through migration and proliferation of endothelial cells (56). sEng act as anti-angiogenic factor through inhibition of TGF- $\beta$ signaling and consequent lack of activation of eNOS (Figure 1). Furthermore, sEng binds to the bone morphogenetic protein (BMP)-9 and induces synthesis of endothelin-1 from endothelial cells, which has highly vasoconstrictor properties $(57,58)$. Production of sEng is enhanced in hypoxic conditions and has opposite action in comparison to membrane endoglin.

Tarasevičienè and colleagues investigated the possibility of prediction of preeclampsia by detection of sFlt-1, PlGF, sFlt-1/PIGF ratio and uterine artery Doppler parameters: PI and RI (59). These authors designed case-control study which involved 72 pregnant women with preeclampsia and 72 women with physiological pregnancy, and based on obtained results thay concluded that sFlt-1/PlGF ratio and PlGF are more powerful predictors of preeclampsia compared to sFlt-1, PI and RI, and moreover, that these two parameters are quite sufficient for diagnostic of early preeclampsia. Benovská and coworkers assessed possibility of early prediction of preeclampsia thorough analysis of sFlt-1, PlGF, sFlt-1/PlGF ratio in 120 pregnant women whose gestational age was between 16 and 20 weeks (60). They made conclusion that all mentioned parameters, but in particular sFlt-1/PlGF ratio, can predict onset of preeclampsia in early pregnancy, even 10 to 15 weeks before it occurs. Similar conclusion made Caillon and coauthors based on analysis of sFlt-1/PlGF ratio of 67 high-risk pregnant women (61). The investigation of AbdelHalim and colleagues included 107 pregnant women with preeclampsia and 93 healthy, normo- 
tensive pregnant women (62). Authors, among others, measured sEng in serum and showed that higher values of sEng were present in blood of women with preterm labor and adverse fetal outcome compared to term labor and favorable fetal outcome. Meta-analysis conducted by Allen and coauthors included 30 studies and 65,538 women and dealt with questioning of abnormal values of circulating biomarkers and preeclampsia (63). Among other biomarkers, these authors concluded that sEng was significantly associated with early as well as late onset of preeclampsia. Moore Simas and coworkers recommended assessment of sFlt-1 and sEng for prediction of preeclampsia (64).

Based on results on above mentioned investigations it can be concluded that angiogenic biomarkers are relatively reliable tool in prediction of preeclampsia. However, in order to improve the accuracy of prediction it is always better to determine several biomarkers in the same time.

\section{CONCLUSION}

Bearing in mind that preeclampsia can be severe and result in adverse fetal and maternal outcome, as well as that incidence of preeclampsia has a continuous upward trend, it is very important to develop specific and reliable predictive algorithms in order to enable early initiation of therapy. Aggravating circumstance is that preeclampsia has heterogeneous origin, and due to this fact, the value of individual markers can vary significantly. There is a constant tendency for creating comprehensive algorithm for prediction of preeclampsia which would be sufficiently specific and sensitive, and in the same time cheap and available. In that sense, new clinical studies are needed to show the most effective combination of parameters in the predeclampsia prediction.

\section{REFERENCES}

1. Olson-Chen, C. \& Seligman, N.S. (2016). Hypertensive Emergencies in Pregnancy. Crit. Care. Clin., 32(1), 29-41.

2. Lo, J.O., Mission, J.F. \& Caughey, A.B. (2013). Hypertensive disease of pregnancy and maternal mortality. Curr. Opin. Obstet. Gynecol., 25(2), 124-32.

3. American College of Obstetricians and Gynecologists. (2013). Task Force on Hypertension in Pregnancy. Hypertension in pregnancy. Report of the American College of Obstetricians and Gynecologists' Task Force on Hypertension in Pregnancy. Obstet. Gynecol., 122(5), 1122-31.

4. Tranquilli, A.L., Dekker, G., Magee, L., Roberts, J., Sibai, B.M., Steyn, W., Zeeman, G.G. \& Brown, M.A. (2014). The classification, diagnosis and management of the hypertensive disorders of pregnancy: A revised statement from the ISSHP. Pregnancy. Hypertens., 4(2), 97-104.

5. Sawchuck, D.J. \& Wittmann, B.K. (2014). Pre-eclampsia renamed and reframed: Intra-abdominal hypertension in pregnancy. Med. Hypotheses., 83(5), 619-32.
6. Cunningham, M.W. Jr \& LaMarca, B.D. (2018). The Risk of Cardiovascular Disease, End-Stage Renal Disease, and Stroke in Post-Partum Women and their Fetuses after a Hypertensive Pregnancy. Am. J. Physiol. Regul. Integr. Comp. Physiol., DOI: 10.1152/ajpregu.00218.2017.

7. Dildy, G.A. 3rd, Belfort, M.A. \& Smulian, J.C. (2007). Preeclampsia recurrence and prevention. Semin. Perinatol., 31(3), 135-41.

8. Duckitt, K. \& Harrington, D. (2005). Risk factors for pre-eclampsia at antenatal booking: systematic review of controlled studies. BMJ., 330(7491), 565.

9. Mayer-Pickel, K., Stern, C., Eberhard, K., Lang, U., Obermayer-Pietsch, B. \& Cervar-Zivkovic, M. (2018). Angiogenic factors in pregnancies of women with antiphospholipid syndrome and systemic lupus erythematosus. J. Reprod. Immunol., 127, 19-23.

10. Redman, C.W. (2011). Preeclampsia: a multi-stress disorder. Rev. Med. Interne., 32 Suppl 1, S41-4.

11. Young, B.C., Levine, R.J. \& Karumanchi, S.A. (2010). Pathogenesis of preeclampsia. Annu. Rev. Pathol., 5, 173-92.

12. Velauthar, L., Plana, M.N., Kalidindi, M., Zamora, J., Thilaganathan, B., Illanes, S.E., Khan, K.S., Aquilina, J. and Thangaratinam S. (2014). First-trimester uterine artery Doppler and adverse pregnancy outcome: a meta-analysis involving 55,974 women. Ultrasound. Obstet. Gynecol., 43(5), 500-7.

13. Khong, S.L., Kane, S.C., Brennecke, S.P. \& da Silva Costa, F. (2015). First-trimester uterine artery Doppler analysis in the prediction of later pregnancy complications. Dis. Markers., 2015, 679730.

14. Sánchez-Aranguren, L.C., Espinosa-González, C.T., González-Ortiz, L.M., Sanabria-Barrera, S.M., RiañoMedina, C.E., Nuñez, A.F., Ahmed, A., Vasquez-Vivar, J. \& López, M. (2018). Soluble Fms-Like Tyrosine Kinase-1 Alters Cellular Metabolism and Mitochondrial Bioenergetics in Preeclampsia. Front. Physiol., 9, 83.

15. Levine, R.J., Lam, C., Qian, C., Yu, K.F., Maynard, S.E., Sachs, B.P., Sibai, B.M., Epstein, F.H., Romero, R., Thadhani, R. \& Karumanchi, S.A. (2006). CPEP Study Group. Soluble endoglin and other circulating antiangiogenic factors in preeclampsia. N. Engl. J. Med., 355(10), 992-1005.

16. Petsas, G., Jeschke, U., Richter, D.U., Minas, V., Hammer, A., Kalantaridou, S., Toth, B., Tsatsanis, C., Friese, K. \& Makrigiannakis, A. (2012). Aberrant expression of corticotropin-releasing hormone in pre-eclampsia induces expression of FasL in maternal macrophages and extravillous trophoblast apoptosis. Mol. Hum. Reprod., 18(11), 535-45.

17. De Villiers, C.P., Hedley, P.L., Placing, S., Wøjdemann, K.R., Shalmi, A.C., Carlsen, A.L., Rode, L., Sundberg, K., Tabor, A. \& Christiansen, M. (2017). Placental protein-13 (PP13) in combination with PAPP-A and free leptin index (fLI) in first trimester maternal serum screening for severe and early preeclampsia. Clin. Chem. Lab. Med., 56(1), 65-74. 
18. Fleischer, A., Schulman, H., Farmakides, G., Bracero, L., Grunfeld, L., Rochelson, B. \& Koenigsberg M. (1986). Uterine artery Doppler velocimetry in pregnant women with hypertension. Am J Obstet Gynecol., 154(4), 806-13.

19. Sharma, S., Singh, S., Gujral, U., Oberoi, U. \& Kaur, R. (2011). Uterine Artery Notching on Color Doppler Ultrasound and Roll over Test in Prediction of Pregnancy Induced Hypertension. J. Obstet. Gynaecol. India., 61(6), 649-51.

20. Konje, J.C., Kaufmann, P., Bell, S.C. \& Taylor, D.J. (2001). A longitudinal study of quantitative uterine blood flow with the use of color power angiography in appropriate for gestational age pregnancies. Am. J. Obstet. Gynecol., 185(3), 608-13.

21. Sharma, N., Jayashree, K. \& Nadhamuni, K. (2018). Maternal history and uterine artery wave form in the prediction of early-onset and late-onset preeclampsia: A cohort study. Int. J. Reprod. Biomed. (Yazd)., 16(2), 109-14.

22. Pedroso, M.A., Palmer, K.R., Hodges, R.J., Costa, F.D.S. \& Rolnik, D.L. (2018). Uterine Artery Doppler in Screening for Preeclampsia and Fetal Growth Restriction. Rev. Bras. Ginecol. Obstet., 40(5), 287-93.

23. Tan, M.Y., Syngelaki, A., Poon, L.C., Rolnik, D.L., O'Gorman, N., Delgado, J.L., Akolekar, R., Konstantinidou, L., Tsavdaridou, M., Galeva, S., Ajdacka, U., Molina, F.S., Persico, N., Jani, J.C., Plasencia, W., Greco, E., Papaioannou, G., Wright, A., Wright, D. \& Nicolaides, K.H. (2018). Screening for pre-eclampsia by maternal factors and biomarkers at 11-13 weeks' gestation. Ultrasound. Obstet. Gynecol., DOI: 10.1002/uog.19112

24. Abdel Razik, M., Mostafa, A., Taha, S. \& Salah, A. (2018). Combined Doppler ultrasound and platelet indices for prediction of preeclampsia in high-risk pregnancies. J. Matern. Fetal. Neonatal. Med., DOI: 10.1080/14767058.2018.1481953

25. González-González, N.L., González Dávila, E., Padrón, E., Armas Gonzalez, M. \& Plasencia, W. (2018). Value of Placental Volume and Vascular Flow Indices as Predictors of Early and Late Preeclampsia at First Trimester. Fetal. Diagn. Ther., DOI: 10.1159/000481433

26. Porto, L.B., Brandão, A.H.F., Leite, H.V. \& Cabral, A.C.V. (2017). Longitudinal evaluation of uterine perfusion, endothelial function and central blood flow in early onset pre-eclampsia. Pregnancy. Hypertens., 10, 161-64.

27. Navaratnam, K., Abreu, P., Clarke, H., Jorgensen, A., Alfirevic, A. \& Alfirevic, Z. (2017). Evaluation of agreement of placental growth factor (PlGF) tests and the soluble FMS-like tyrosine kinase 1 (sFlt-1)/PlGF ratio, comparison of predictive accuracy for pre-eclampsia, and relation to uterine artery Doppler and response to aspirin. J. Matern. Fetal. Neonatal. Med., DOI: 10.1080/14767058.2017.1373760.

28. Lee, R.C., Feinbaum, R.L. \& Ambros, V. (1993). The C. elegans heterochronic gene lin- 4 encodes small RNAs with antisense complementarity to lin-14. Cell., 75(5), 843-54.
29. Mens, M.M.J. \& Ghanbari, M. (2018). Cell Cycle Regulation of Stem Cells by MicroRNAs. Stem. Cell. Rev., 14(3), 309-22.

30. Soltanzadeh-Yamchi, M., Shahbazi, M., Aslani, S. \& Mohammadnia-Afrouzi, M. (2018). MicroRNA signature of regulatory $\mathrm{T}$ cells in health and autoimmunity. Biomed. Pharmacother., 100, 316-23.

31. Lam, I.K.Y., Chow, J.X., Lau, C.S. \& Chan, V.S.F. (2018). MicroRNA-mediated immune regulation in rheumatic diseases. Cancer. Lett., 431, 201-12.

32. Bhaskaran, M. \& Mohan, M. (2014). MicroRNAs: history, biogenesis, and their evolving role in animal development and disease. Vet. Pathol., 51(4), 759-74.

33. Lou, W., Liu, J., Gao, Y., Zhong, G., Chen, D., Shen, J., Bao, C., Xu, L., Pan, J., Cheng, J., Ding, B. \& Fan, W. (2017). MicroRNAs in cancer metastasis and angiogenesis. Oncotarget., 8(70), 115787-802.

34. Data available on miRBase: the microRNA database http://www.mirbase.org/cgi-bin/browse.pl?org=hsa Data retracted on July 10th 2018.

35. Pineles, B.L., Romero, R., Montenegro, D., Tarca, A.L., Han, Y.M., Kim, Y.M., Draghici, S., Espinoza, J., Kusanovic, J.P., Mittal, P., Hassan, S.S. \& Kim, C.J. (2007). Distinct subsets of microRNAs are expressed differentially in the human placentas of patients with preeclampsia. Am. J. Obstet. Gynecol., 196(3), 261.e1-6.

36. Zhang, Y., Diao, Z., Su, L., Sun, H., Li, R., Cui, H. \& Hu, Y. (2010). MicroRNA-155 contributes to preeclampsia by down-regulating CYR61. Am. J. Obstet. Gynecol., 202(5), 466.e1-7.

37. Gellhaus, A., Schmidt, M., Dunk, C., Lye, S.J., Kimmig, R. \& Winterhager, E. (2006). Decreased expression of the angiogenic regulators CYR61 (CCN1) and NOV (CCN3) in human placenta is associated with pre-eclampsia. Mol. Hum. Reprod., 12(6), 389-99.

38. Dai, Y., Diao, Z., Sun, H., Li, R., Qiu, Z. \& Hu, Y. (2011). MicroRNA-155 is involved in the remodelling of human-trophoblast-derived HTR-8/SVneo cells induced by lipopolysaccharides. Hum. Reprod., 26(7), 1882-91.

39. Enquobahrie, D.A., Abetew, D.F., Sorensen, T.K., Willoughby, D., Chidambaram, K. \& Williams, M.A. (2011). Placental microRNA expression in pregnancies complicated by preeclampsia. Am. J. Obstet. Gynecol., 204(2), 178.e12-21.

40. Muralimanoharan, S., Maloyan, A., Mele, J., Guo, C., Myatt, L.G. \& Myatt, L. (2012). MIR-210 modulates mitochondrial respiration in placenta with preeclampsia. Placenta., 33(10), 816-23.

41. Gunel, T., Zeybek, Y.G., Akçakaya, P., Kalelioğlu, I., Benian, A., Ermis, H. \& Aydınl, K. (2011). Serum microRNA expression in pregnancies with preeclampsia. Genet. Mol. Res., 10(4), 4034-40.

42. Shen, L., Li, Y., Li, R., Diao, Z., Yany, M., Wu, M., Sun, H., Yan, G. \& Hu Y. (2018). Placenta-associated serum exosomal miR-155 derived from patients with preeclampsia inhibits eNOS expression in human umbilical vein endothelial cells. Int. J. Mol. Med., 41(3), 1731-1739. 
43. Winger, E.E., Reed, J.L., Ji, X. \& Nicolaides, K. (2018). Peripheral blood cell microRNA quantification during the first trimester predicts preeclampsia: Proof of concept. PLoS One., 13(1), e0190654.

44. Luque, A., Farwati, A., Crovetto, F., Crispi, F., Figueras, F., Gratacós, E. \& Aran, J.M. (2014). Usefulness of circulating microRNAs for the prediction of early preeclampsia at first-trimester of pregnancy. Sci. Rep., 4, 4882.

45. Ngene, N.C. \& Moodley, J. (2018). Role of angiogenic factors in the pathogenesis and management of preeclampsia. Int. J. Gynaecol. Obstet., 141(1), 5-13.

46. Bates, D.O., Beazley-Long, N., Benest, A.V., Ye, X., Ved, N., Hulse, R.P., Barratt, S., Machado, M.J., Donaldson, L.F., Harper, S.J., Peiris-Pages, M., Tortonese, D.J., Oltean, S. \& Foster, R.R. (2018). Physiological Role of Vascular Endothelial Growth Factors as Homeostatic Regulators. Compr. Physiol., 8(3), 955-979.

47. Powe, C.E., Levine, R.J. \& Karumanchi, S.A. (2011). Preeclampsia, a disease of the maternal endothelium: the role of antiangiogenic factors and implications for later cardiovascular disease. Circulation., 123(24),

48. Chau, K., Hennessy, A. \& Makris, A. (2017). Placental growth factor and pre-eclampsia. J. Hum. Hypertens., 31(12), 782-786.

49. Abou El Hassan, M., Diamandis, E.P., Karumanchi, S.A., Shennan, A.H. \& Taylor, R.N. (2015). Preeclampsia: an old disease with new tools for better diagnosis and risk management. Clin. Chem., 61(5), 694-8.

50. Weissgerber, T.L., Rajakumar, A., Myerski, A.C., Edmunds, L.R., Powers, R.W., Roberts, J.M., Gandley, R.E. \& Hubel, C.A. (2014). Vascular pool of releasable soluble VEGF receptor-1 (sFLT1) in women with previous preeclampsia and uncomplicated pregnancy. J. Clin. Endocrinol. Metab., 99(3), 978-87.

51. Palmer, K.R., Tong, S. \& Kaitu'u-Lino, T.J. (2017). Placental-specific sFLT-1: role in pre-eclamptic pathophysiology and its translational possibilities for clinical prediction and diagnosis. Mol. Hum. Reprod., 23(2), 69-78.

52. Gregory, A.L., Xu, G., Sotov, V. \& Letarte, M. (2014). Review: the enigmatic role of endoglin in the placenta. Placenta., 35 Suppl, S93-9.

53. Cheifetz, S., Bellon, T., Cales, C., Vera, S., Bernabeu, C., Massague, J. \& Letarte, M. (1992). Endoglin is a component of the transforming growth factor-beta receptor system in human endothelial cells. J. Biol. Chem., 267(27), 19027e30.

54. Toporsian, M., Gros, R., Kabir, M.G., Vera, S., Govindaraju, K., Eidelman, D.H., Husain, M. \& Letarte, M.
(2005). A role for endoglin in coupling eNOS activity and regulating vascular tone revealed in hereditary hemorrhagic telangiectasia. Circ. Res., 96(6), 684e92.

55. Li, C.G., Wilson, P.B., Bernabeu, C., Raab, U., Wang, J.M. \& Kumar, S. (1998). Immunodetection and characterization of soluble CD105-TGF-ß complexes. J. Immunol. Methods., 218, 85e93.

56. Jardim, L.L., Rios, D.R., Perucci, L.O., de Sousa, L.P., Gomes, K.B. \& Dusse, L.M. (2015). Is the imbalance between pro-angiogenic and anti-angiogenic factors associated with preeclampsia? Clin. Chim. Acta., 447, 34-8.

57. David, L., Mallet, C., Mazerbourg, S., Feige, J.J. \& Bailly, S. (2007). Identification of BMP9 and BMP10 as functional activators of the orphan activin receptor-like kinase 1 (ALK1) in endothelial cells. Blood., 109(5), 1953 e61.

58. Possomato-Vieira, J.S. \& Khalil, R.A. (2016). Mechanisms of Endothelial Dysfunction in Hypertensive Pregnancy and Preeclampsia. Adv Pharmacol., 77, 361431.

59. Tarasevičienè, V., Grybauskienė, R. \& Mačiulevičienė, R. (2016). sFlt-1, PlGF, sFlt-1/PlGF ratio and uterine artery Doppler for preeclampsia diagnostics. Medicina. (Kaunas)., 52(6), 349-353.

60. Benovská, M., Opluštilová, A., Pinkavová, J., Hodická, Z. \& Cermáková, Z. (2018). The New Possibilities in Early Diagnosis of Preeclampsia by Soluble fms-Like Tyrosine Kinase-1 and Placental Growth Factor in 1620 Weeks Gestation. Lab. Med., 49(2), 112-117.

61. Caillon, H., Tardif, C., Dumontet, E., Winer, N. \& Masson, D. (2018). Evaluation of sFlt-1/PlGF Ratio for Predicting and Improving Clinical Management of Preeclampsia: Experience in a Specialized Perinatal Care Center. Ann. Lab. Med., 38(2), 95-101.

62. AbdelHalim, R.M., Ramadan, D.I., Zeyada, R., Nasr, A.S. \& Mandour, I.A. (2016). Circulating Maternal Total Cell-Free DNA, Cell-Free Fetal DNA and Soluble Endoglin Levels in Preeclampsia: Predictors of Adverse Fetal Outcome? A Cohort Study. Mol. Diagn. Ther., 20(2), 135-49.

63. Allen, R.E., Rogozinska, E., Cleverly, K., Aquilina, J. \& Thangaratinam, S. (2014). Abnormal blood biomarkers in early pregnancy are associated with preeclampsia: a meta-analysis. Eur. J. Obstet. Gynecol. Reprod. Biol., 182, 194-201.

64. Moore Simas, T.A., Crawford, S.L., Bathgate, S., Yan, J., Robidoux, L., Moore, M. \& Maynard, S.E. (2014). Angiogenic biomarkers for prediction of early preeclampsia onset in high-risk women. J. Matern. Fetal. Neonatal. Med., 27(10), 1038-48. 